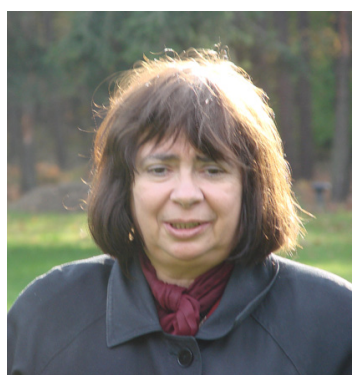

\title{
Ewa Machut-Mendecka
}

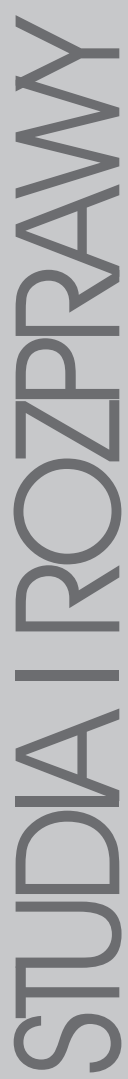

Ewa Machut-Mendecka - jest profesorem zwyczajnym Uniwersytetu Warszawskiego, była długoletnim pracownikiem Szkoły Wyższej Psychologii Społecznej w Warszawie. Interesuje się literaturą, kulturą, psychologią, antropologią świata islamu - tradycją i społeczeństwem tego obszaru ze szczególnym uwzględnieniem problematyki kobiety, mediów i kultury popularnej; zajmuje się również językiem arabskim i jego dialektami. Obszar swoich zainteresowań zna z licznych podróży. Jest zastępcą redaktora naczelnego „Albo albo. Problemy Psychologii i Kultury" (Wydawnictwo ENETEIA). Opublikowała m.in. Główne kierunki rozwojowe dramaturgii arabskiej (1992), Studies in Arabic Theatre and Literature (2000), Archetypy islamu (2003), Świat tradycji arabskiej (2005), Na szlakach Sindbada. Koncepcje współczesnej prozy arabskiej (2009), Kultura arabska, mity, literatura, polityka (2012). 


\section{Współczesna literatura arabska jako obraz otaczającej rzeczywistości}

DOI: http://dx.doi.org/10.12775/LC.2014.001

spółczesna literatura arabska, powstająca po okresie kolonialnym, stanowiła całkiem inną jakość niż wcześniejsza - klasyczna (VII-XIX w.), a w jej ramach kształtowały się słabo jak dotąd rozwinięte rodzaje i gatunki literackie, w tym poezja „biała” i „wolna”, powieść, nowela i opowiadanie oraz dramat. Głównymi układami odniesienia o charakterze politycznym i społecznym dla literatury w okresie jej powstawania były Imperium Osmańskie chylące się do upadku i kolonializm, i wobec obu też pozostawała w opozycji. Niemniej rozwijała się drogą syntezy obcych i rodzimych środków literackich, w swojej warstwie znaczeniowej i ideologicznej starała się określić przede wszystkim kształt i sens otaczającej rzeczywistości.

Klasycyzm odszedł w przeszłość, rozpoczęła się nowa epoka. W historii krajów arabskich nastąpiła decydująca zmiana kulturowa i polityczna, pod wpływem której miała się zmieniać sfera obyczajowa i struktury społeczne. Kształtowały się nowoczesne instytucje. Światly uczony Talat Harb (1867-1941) powołał do życia pierwszy bank w Egipcie, a wielki reformator i twórca modernizmu egipskiego Muhammad Abduh (1849-1905), jako mufti kraju, pozwolił Egipcjanom pożyczać na procent, czyli uwolnił ich od zarzutu riby - lichwy, co ograniczało rozwój muzułmańskiej bankowości. Uczony wykładał zasady nowoczesnej ekonomii, zachęcając młodzież do rozwoju gospodarki, zwłaszcza postulował przemiany od feudalizmu do kapitalizmu, choć zresztą ten pierwszy ze względu na znaczenie struktur plemiennych nie był tak całkiem rozwinięty w świecie arabskim.

Feudałowie i arystokraci tworzyli jedną wielką klasę, dumną z pochodzenia i majątków, pełni wiary we własne możliwości w nowych czasach, pielęgnowali tradycję, otaczając szacunkiem, jeśli nie kultem, wielką literaturę klasyczną i rozwijali interesy. Sekundowali też gorąco rozwojowi nowej myśli, w tym literackiej, w swoich krajach.

W nowej literaturze arabskiej proza i dramat są sobie pokrewne, ponieważ do obu tych rodzajów sięgają często ci sami autorzy w poszukiwaniu środków wyrazu, zwłaszcza że punktem odniesienia przestaje być klasycyzm. Historia tej literatury nie jest zbyt długa, jej faza dojrzała liczy - poczynając w przybliżeniu od lat 20., z różnymi przesunięciami w czasie, jeden wiek lub mniej. Jak piszą J. Bielawski, K. Skarżyńska-Bocheńska i J. Jasińska w Nowej i wspótczesnej literaturze arabskiej XIX i XX w.: 
Lata XX wieku stanowią początek nowej prozy arabskiej, która powstała w dużej mierze pod wpływem europejskiej tradycji literackiej, czerpiąc z niej wzory nowych dla Arabów gatunków literackich, opowiadania, noweli i powieści. Twórczość ta, w przeciwieństwie do dawnej, koncentruje się na aktualnej rodzimej problematyce społecznej i narodowej. Najwcześniejsze egipskie powieści są jeszcze próbą dostosowywania dawnych arabskich form tradycyjnego stylu ozdobnej rymowanej prozy do krytyki stosunków współczesnego autorom społeczeństwa. Bardzo szybko następuje jednak rozwój noweli, opowiadania i powieści pisanych nowym, swobodnym stylem i pojawia się plejada pisarzy, którzy kładą zręby pod współczesną literaturę Egiptu, wytyczając zarazem drogę literatom innych krajów arabskich ${ }^{1}$.

Od lat 20. XX wieku rozpoczyna się też dojrzała faza rozwoju arabskiej dramaturgii, jakkolwiek autorzy wspomnianej historii literatury ustalają tu datę nieco późniejszą:

Stopniowo, w miarę powstawania coraz doskonalszych przekładów arcydzieł dramaturgii europejskiej i prezentowania ich na scenie przez stojących na coraz wyższym poziomie egipskich autorów, w kołach literackich zaczęło się pojawiać zainteresowanie teatrem i twórczością dramatyczną. Wtedy to właśnie, na przełomie lat trzydziestych XX w. kształtuje się arabska literatura dramatyczna w formie poetyckiej i proząa 2 .

Jednakże dramaturgia arabska rozwijała się od 2. poł. XIX wieku, a w latach 20. twórczość Muhammada Tajmura (1892-1921) - dramaty powstałe między 1918 i 1921 - stanowiły nową jakość literacką, rozwijając się w kierunku realizmu krytycznego. Również jeden z nestorów dramaturgii arabskiej, Taufik al-Hakim (1898-1987) pisał utwory dramatyczne już w latach 20. (zadebiutował w 1918 r. sztuką alegoryczną Ad-Dajf as-sakil - Uciążliwy gość), opublikował m.in. głośną komedię Il-Mara il-gidida (Nowa kobieta)³ , w której podjął jeden z palących tematów modernizmu, jakim była emancypacja kobiet, zdaniem autora nieco przesadna.

Twórczość tych samych pisarzy plasuje się i w różnych gatunkach, i w różnych nurtach literackich. Najwybitniejsi autorzy to pisarze poszukujący, którzy przerzucają się od konwencji do konwencji i poruszają cały wachlarz tematów, jak Taufik al-Hakim, prozaik, poeta i dramaturg, neoklasyk i realista, nowatorski dramatopisarz.

Prozaicy i dramatopisarze są ekstrawertykami literatury, ponieważ z pasją poszukują swoich inspiracji pisarskich przede wszystkim w otaczającym świecie, jego najbardziej palących problemach i ukrytych zjawiskach. Rozumiem to zgodnie z koncepcją ekstrawersji Carla Gustava Junga:

Wiedzie on [ekstrawertyk - E. M.-M.] życie w ten sposób, że wyraźnie widać, iż przedmiot jako czynnik determinujący odgrywa w jego świadomości większą rolę niż subiektywny podmiot. Owszem, człowiek ów posiada też subiektywne poglądy, ale ich determinująca siła jest mniejsza od siły wywieranej przez zewnętrzne warunki obiektywne ${ }^{4}$.

\footnotetext{
1 J. Bielawski, K. Skarżyńska-Bocheńska, J. Jasińska, Nowa i współczesna literatura arabska XIX i XX w. Literatura arabskiego Wschodu, Warszawa 1978, s. 423.

2 Ibidem, s. 573.

3 E. Machut-Mendecka, Współczesny dramat egipski lat 1870-1975, Warszawa 1984, s. 85-88.

${ }^{4}$ C. G. Jung, Typy psychologiczne, tłum. R. Reszke, Warszawa 1977, s. 373.
} 
To obszar arabski po okresie tureckim i już w trakcie kolonializmu, nie mówiąc o czasach późniejszych, staje się głównym punktem odniesienia dla twórców i z niego czerpią oni swoje inspiracje. Termin „literatura zaangażowana” wywołuje w polskiej i zachodniej krytyce dziś na ogół nie najlepsze skojarzenia, ale bez jego pejoratywnej otoczki byłby on jak najbardziej odpowiedni dla charakterystyki współczesnej literatury arabskiej. Pisarze arabscy bowiem, w tym poeci, identyfikują się w swoich utworach głęboko i spontanicznie ze swoją ziemią, a sprawy publiczne w ich ujęciach stają się osobiste i intymne. Krytyka arabska wprowadziła też termin al-adab al-multazim - literatura zaangażowana, i w przypadku większości twórców z jej obszaru jest to pełny iltizam (zaangażowanie). Świat arabski w początkach fazy dojrzałej literatury fascynował intelektualistów jako wciąż młody, godny rozpoznania i opisu.

Z prozy i dramatu, jako form nowej literatury arabskiej, wyłaniają się nurty literackie, których źródłem jest stosunek pisarzy do rzeczywistości, prowokujący do tworzenia określonych konwencji literackich i żonglowania środkami wyrazu. Powstają one dzięki wybitnym twórcom fazy dojrzałej literatury, o zbliżonych datach urodzenia, a nawet jeśli zachodzą między nimi różnice pokoleniowe, tworzą w podobnych okresach, wielu z nich jeszcze w pierwszej dekadzie XXI wieku. Odchodzi wówczas wielu z jej nestorów (jeśli nie prekursorów), jak: Munis ar-Razzaz (Jordania 2002), Szauki Abd al-Hakim (Egipt 2003), Mahmud Dijab (Egipt 2003), Muhammad Szukri (Maroko 2003), Abd ar-Rahman Munif (Jordania 2004), Muhammad al-Maghut (Syria 2006), Abd al-Karim Ghallab (Maroko 2006), egipski prozaik - noblista Nadżib Mahfuz (2006), Nazik al-Mala'ika (Irak 2007), At-Tajjib Salih (Sudan 2009), Tahir al-Wattar (Algieria 2010).

A przecież wielu z nich rozwijało swoją aktywność literacką w latach 70. i 80., kiedy tworzyli jeszcze pionierzy prozy i dramatu w świecie arabskim, Egipcjanie, Mahmud Tajmur (1894-1973) i Taufik al-Hakim. Ze względu na spójność fazy dojrzałej literatury może wygodniej byłoby mówić o jej nurtach niż okresach.

W ramach tej typologii literatura przejawia kilka tendencji:

1. Zmierza do wyrażania przemian $\mathrm{w}$ fabułach kształtujących się w porządku przyczynowo-skutkowym z uwzględnieniem czasu linearnego. Twórczość ta jest bliska szeroko pojętemu realizmowi, choć pojęcie to należałoby odróżnić od określenia używanego dla literatury europejskiej.

2. Podejmuje współczesne problemy arabskie w kategoriach odniesień do przeszłości, historii, legend i w ujęciach abstrakcyjnych, z uwzględnieniem głównie synchronii.

3. Sięga po znaczenia uniwersalne wyłaniające się z historii i legend, czas rozwija się głównie w porządku synchronicznym bądź w formach abstrakcyjnych.

Twórczość tych nurtów, zwłaszcza dwóch pierwszych, pozwala zrekonstruować istotne zjawiska modernizującego się świata arabskiego, z ich znaczeniem i do pewnego stopnia chronologią.

\section{Świat w trakcie przemian}

Twórczość prozaików i dramaturgów obrazuje początki i rozwój modernizmu w krajach arabskich m.in. w jednoznacznych ujęciach, podporządkowanych kategorii przyczynowości, i gdy czas rozwija się jako linearny, a jej bohater jest referencyjny i odpowiada postaci 
„człowieka z krwi i kości” obecnej w wyznaczonej jej przestrzeni. Twórczość tę reprezentują m.in. Numan Aszur (1918-1987), Salwa Bakr (ur. 1950), Taufik al-Hakim, Nadzzib Mahfuz (1911-2006) , Ahdaf Suwajf (ur. 1950), Abd ar-Rahman asz-Szarkawi (1920-1987), Mahmud Tajmur Madżid Tubijja (ur. 1938), Sad ad-Din al-Wahba (1925-1997, Egipt), Abd ar-Rahman Madżid ar-Rubaji (ur. 1939, Irak), Mubarak Rabi (ur. 1940, Maroko) Hajdar Hajdar (ur. 1938), Walid Ichlasi (ur. 1935), Hanna Mina (ur. 1924 Syria), chociaż piszą też utwory utrzymane w innej konwencji.

Literatura tego nurtu dowodzi twórczej roli w rozwoju modernizmu wspomnianej arystokracji wyłaniającej się z klasy feudalnej, dumnej ze swojego pochodzenia, tradycji rodowej oraz patriotyzmu. Tak jak w Charitat al-hubb (Mapa miłości) Ahdaf Suwajf, ta właśnie klasa sięga po najbardziej zasłużone miejsca w kraju: Mahmud Sami al-Barudi (1838-1904) jest wielkim poetą, egipskim prekursorem odrodzenia poezji; uczestnik słynnego powstania Urabiego Paszy, ukarany zesłaniem, wraca do kraju jako niewidomy i pełen goryczy starzec. Jego bratanek, Szarif al-Barudi skupia wokół siebie opozycję sprzeciwiającą się władzy brytyjskiej. W salonie tego arystokraty, wciąż z tej samej powieści, gromadzą się bohaterowie Egiptu o nieprzemijającej sławie.

Dumna arystokracja arabska XIX i XX wieku broniła tradycji i patronowała przemianom. Dlatego też prozaik i dramaturg syryjski Walid Ichlasi broni jej samej - znakomitych rodów ziemiańskich w dramacie Haza an-nahr al-madżnun (Ta szalona rzeka) i w powieści Zahrat as-sandal (Kwiat drzewa sandałowego). W dramacie pisarz opisuje ją z nutą nostalgii. Na przełomie XIX i XX stuleciu stanowiła bowiem ostoję porządku społecznego, a teraz pod wpływem modernizmu odchodziła w przeszłość Pisarz roztacza barwny obraz tej klasy, która wciąż dumna i pełna życia, wkracza na ziemiach syryjskich w stadium dekadencji. W powieści Ichlasiego syryjski, tradycyjny dom wciąż trwa, niezachwiany w swojej świetności, co zawdzięcza nestorce rodu Wahhub, wdowie po wielkim miejscowym beju, która przeżyła śmierć swoich bliskich, w tym syna - został zabity w czasie walk narodowo-wyzwoleńczych - ale wciąż niewzruszona, z kamienną twarzą, w eleganckim dżilbabie patronuje kolejnym weselom, pogrzebom i narodzinom dzieci. W wielkim domu przypomina królową-matkę doglądającą królestwa ze swego pałacu, pełna dobrych pomysłów i wydając słuszne rozkazy. Pani na swoich włościach włada okolicą w myśl tradycji przodków, nieprzejednana w swoich decyzjach, podejmowanych dla dobra rodziny.

Ojczulek Sa’id, ojciec Lajli zajmował się włościami babki Wahhub, która wydawała na nas wszystkie swoje dochody. Do babki należały sklepy na bazarze w starej dzielnicy i arabskie domy mieszkalne, z których jedne należało wyremontować, inne zburzyć. Zmienily się i unowocześniły rachunki, jakie prowadziła Wahhub, jej majątek liczony dotąd w złocie i srebrze teraz nabrał wartości pieniężnej. Pieniądze szły na wnuki, ich wesela, naukę, pogrzeby, wyjazdy, budowę nowych domów, w których zamieszkiwali krewni uniezależniając się od Al-Ansarijji. Nikt z mieszkańców tej posiadłości nie pamięta, żeby babka kiedykolwiek kupiła sobie choć jedną sztukę biżuterii czy pomyślała o czymś cenniejszym dla siebie. To ona rozdała wszystkie klejnoty i przedmioty, które coś były warte. Mimo to babka domagała się od każdego, kogo było stać, aby płacił jej pewną sumę, którą z kolei rozdzielała między potrzebujących. Nikt nie wiedział, do kogo pójdą jego pieniądze. Opowiadano, że któryś z wnuków zalegał z wpłatą i wówczas babka wezwała go do liwanu, gdzie przesiadywała na swoim miejscu górującym nad Al-Ansarijją, spojrzała na chłopca uważnie, potem wzięła go za rękę i poprowadziła do grobowców, z szacunkiem pochylając przed nimi głowę: 
- Czy widzisz jakieś imiona na grobowcach świętych, naszych przodków ? - zapytała.

Wnuk przyjrzał się uważnie grobowcom, na których nie zauważył żadnych imion, nie było też innych wskazówek, ułatwiających zrozumienie, co babka miała na myśli. Niepewny i zdziwiony zakrzykną:

- Nigdy nie myślałem, że grobowce noszą imiona, przy pomocy których można by je nazywać.

- Mój synu, tu spoczywają nasi przodkowie, wszystko nam zostawili. Dzięki nim mamy dobra i dom, dający nam schronienie, też majątek zdolny nas wyżywić. Nie zostawili nam jednak imion, pod którymi moglibyśmy ich wspominać - powiedziała babka z uśmiechem kładąc mu rękę na ramieniu.

- Bierzemy więc i dajemy w imię historii naszej rodziny - powiedział wnuk łagodnie.

Potem już nikt nie ośmielił się opóźniać swoich wpłat, zasilających następnie fundusz dla potrzebujących ${ }^{5}$.

Mniej szczęścia ma wdowa po potężnym beju egipskim z powieści Egipcjanina Madżida Tubijji Azra min al-Ghurub (Dziewczyna z wioski Ghurub), która zasiada na grobowcu męża, aby nie dopuścić do zalania tego miejsca wodą, czym zagraża decyzja o budowie wodociągu w pobliskiej wiosce. A przecież i ona, i Wahhub miały głośne na całą okolicę wesela, o których wciąż opowiada się legendy. Literatura pokazuje, jak pomimo znaczenia, uroku i zasług wielkie rody, które miały tworzyć nowy świat arabski po okresie klasycyzmu, tracą grunt pod nogami. $\mathrm{Z}$ innych literackich ujęć płynie sugestia, że może warstwa ziemiańsko-arystokratyczna zasłużyła sobie na swój los. Zwłaszcza z twórczości pisarzy egipskich, prozaików i dramaturgów tej miary, co Muhammad i Mahmud Tajmur i Taufik al-Hakim warstwa ta wyłania się jako twór dekadencki i już rachityczny czerpiący siłę ze swoich wad. Oskarżeniem pod jej adresem jest m.in., już w samym swoim tytule, dramat Mahmuda Tajmura Al-Muzajjafun (Fałszerze), w której egipskie warstwy wyższe skłaniają się ku nieuczciwym interesom, malwersacjom i machlojkom.

Młodszy od obu nestorów literatury pisarz Sad ad-Din Wahba już po rewolucji naserowskiej wyśmiewa w komedii sfery wyższe w okresie przedrewolucyjnym:

George: Nigdy nie mieliśmy lepszego premiera niż jego ekscelencja. To nie tylko moje słowa, wszyscy tak twierdzą. Absolutnie wszyscy mówią, że to człowiek na swoim miejscu, uczciwy, nie zdolny do żadnych krętactw.

Hikmat: Jeden ma szczęście, inny nie. Uczciwy bardziej się męczy (wchodzi Marie, siada obok Hikmat i otwiera przed nią katalog).

Marie: Ta jest przepiękna...

Hikmat: Jak możesz, Marie! Mam włożyć coś takiego! Ekscelencja by mnie zabił.

Marie: Dlaczego, proszę pani? Jest pani jeszcze młoda i trzeba się ładnie ubierać. [... ]

George: Ekscelencja to wspaniały człowiek i wszystko będzie dobrze. Wszyscy kochają ekscelencję.

Hikmat: No zobaczymy, czym się skończy ten kryzys rządowy.

George: Ależ dobrze się skończy!

George: Mam małą prośbę.

Hikmat: Co takiego, George?

George: Chcę dostać obywatelstwo egipskie, proszę pani.

${ }^{5}$ Walid Ichlasi, Zahrat as-sandal, Dimaszk [b.d.w.], s. 83-84 
Hikmat: To, napisz podanie.

George: Napisałem, proszę pani, ale to nic nie dało. Potrzebna jest protekcja ${ }^{6}$.

Przemiany społeczne splatają się z obyczajowymi. Hołdują im sfery wyższe w Egipcie, nieświadome swojej już rozpoczynającej się dekadencji, dążą usilnie do przewrotu w sferze obyczajów polegającym na przejmowaniu wzorów europejskich. Krytyka dotyka zwłaszcza arystokratek. W fabułach utworów ich wcielenia poczynają sobie nazbyt swobodnie i arogancko. W jednoaktówce Tajmura Is-Suluk (Odszczepieniec) wyniosła piękność bawi się swoim adoratorem na sposób francuskich dam, co ten zresztą, biegły w sztuce flirtowania, przyjmuje z zadowoleniem. Jako zdemoralizowana, pusta i próżna wyłania się postać młodej mężatki z powieści Taufika al-Hakima Ar-Ribat al-mukaddasa (Święte więzy), pochłoniętej oglądaniem romansów filmowych oraz wynajdywaniem sobie kolejnych miłostek, co pozwala jej oderwać się od nieudanego małżeństwa zawartego, bez uczucia, w ramach własnej świetnej klasy.

Taufik al-Hakim dawał w swoich utworach wyraz niechęci do nadmiernej, krzykliwej emancypacji kobiet egipskich ze sfer wyższych, które wydawały się wierzyć, że Kair jest zachodnią metropolią. Choć był nowoczesnym pisarzem, wykształconym w Paryżu i znawcą literatury europejskiej, nie sekundował gwałtownym przemianom w Egipcie królewskim, świadom ich natury i konsekwencji. Między innymi w autobiograficznej powieści Usfur min asz-szark (Ptak ze wschodu) podkreślał różnice między Zachodem i Wschodem, których wykładnią była opozycja materializmu kultury zachodniej i uduchowienia wschodniej. Taufik al-Hakim w tym i innych swoich utworach opowiadał się przede wszystkim za wyważeniem różnorodnych, złożonych racji, czego dowodził zwłaszcza jego znany traktat At-Ta’adulijja (Równowaga). I w swojej twórczości literackiej zachęcał westernizujące się kobiety egipskie do umiaru. W komedii An-Na'iba al-muhtarama (Szacowna posłanka) ojciec dziecka, którego matka oddaje się polityce i zasiada $\mathrm{w}$ parlamencie, $\mathrm{z}$ trudem radzi sobie $\mathrm{z}$ domem, a dobra żona $\mathrm{w}$ końcu rezygnuje z kariery politycznej na rzecz rodziny. Wybitny humanista, Taufik al-Hakim studzi zapały: przecież nie jest przeciwnikiem przemian, ale zniechęca do działań gwałtownych i ekstremalnych. Potrafi być postępowy w podejściu do problematyki społeczno-politycznej i m.in. w Domu niespetnionych marzeń optuje za spokojnym odchodzeniem od feudalizmu na rzecz kapitalizmu drogą oświaty i rozwoju gospodarki ${ }^{8}$.

Modernizm i przemiany Egiptu są pasją, jeśli nie obsesją Nadżiba Mahfuza. Zjawiska te jako wyraziste i nieuchronne stanowią siłę napędową As-Sulasijji (Trylogia), z jej akcją rozwijającą się od 1917 roku - w niespokojnym okresie, którego kulminację stanowi egipskie powstanie 1919 - po koniec II wojny światowej. W fabule poszczególnych tomów coraz bardziej liczy się zdanie dorosłych dzieci apodyktycznego kupca, który początkowo nie dopuszczał myśli o jakiejkolwiek wolności słowa w rodzinie; dzieci te przeżywają też awans społeczny, ze sfery mieszczańskiej do oczytanej i oświeconej klasy średniej. Przemiany społeczne pociągają za sobą postęp obyczajowy, rozumiany w kategoriach wzrastających swobód jednostki. Na zdecydowany zwrot polityczny, jaki miał nastąpić już po zakończeniu akcji As-Sulasijji, trzeba poczekać jeszcze kilka lat.

\footnotetext{
6 Sad ad-Din Wahba, Bantalun ma'ali al-basza, [w:] Sad ad-Din Wahba, Al-Wazir szal as-salladża, Al-Kahira 1980, s. 508-509.

7 Por. J. Bielawski, K. Skarżyńska-Bocheńska, J. Jasińska, op. cit., s. 488.

8 Por. J. Shalan, Writing the Nation: Emergence of Egypt in the Modern Arabic Novel, [w:] Literature and Nation in the Middle East, (red.) Y. Suleiman, I. Muhawi, Edinburgh 2006, s. 147.
} 


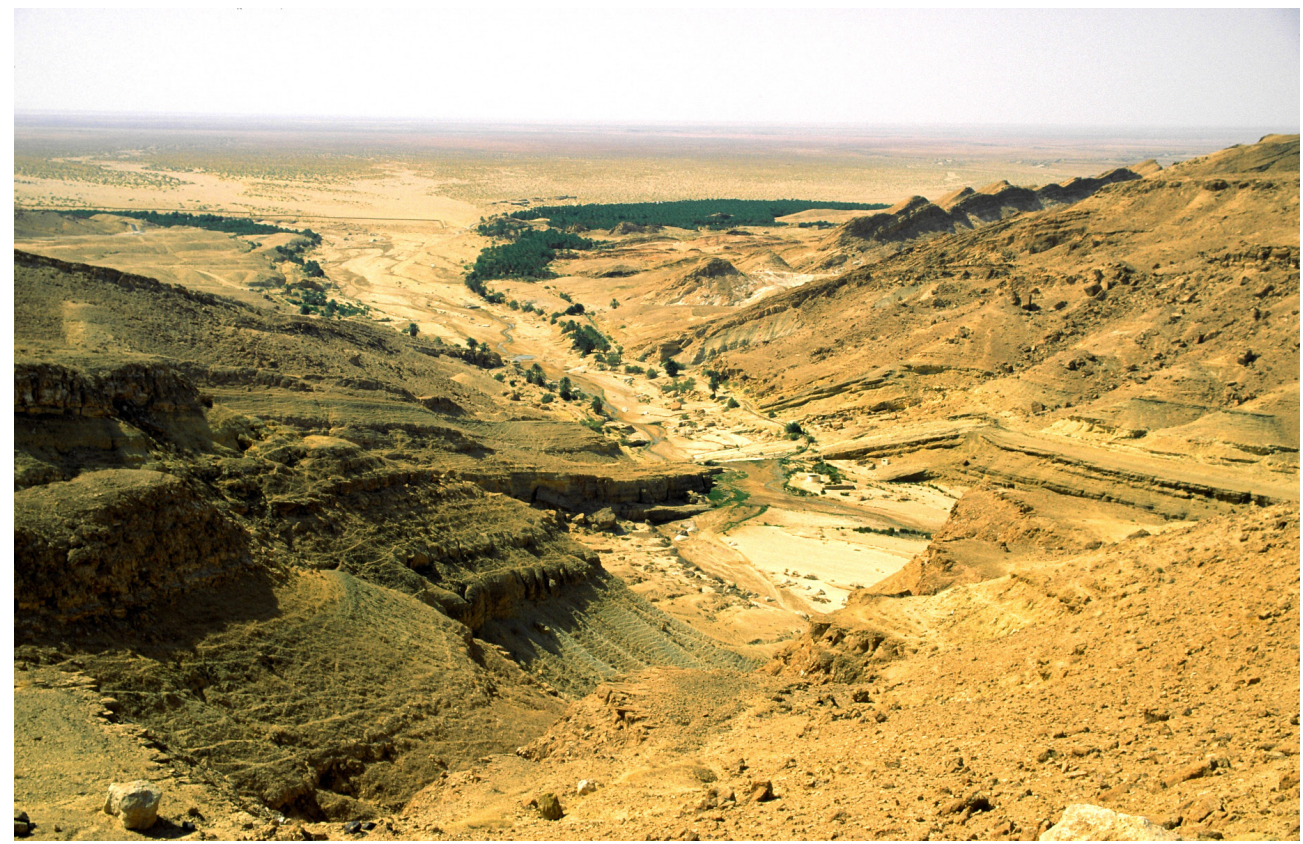

Dolina typu wadi na pustyni w Tunezji

(fot. Z. Preisner)

Niewiele dzieli rewolucję egipską 1952 roku od decydujących przemian ustrojowych czy też wynikających z odzyskiwania niepodległości, w innych krajach arabskich. Jednak Nadżib Mahfuz pozostaje jedynym arabskim noblistą w zakresie literatury, a zatem to, co napisał, liczy się bardzo, zwłaszcza że jego stosunek do rewolucji jest szczególny. Pisarz po wybuchu rewolucji zamilkł na kilka lat, za to w późniejszych utworach As-Siman wa al-charif (Przepiórki i jesień), Złodziej i psy, Rozmowy nad Nilem, Hotel Miramar ${ }^{9}$ i Karnak uparcie i z wielkim zaangażowaniem emocjonalnym powraca do tego przełomowego wydarzenia. W przeciwieństwie do wielu pisarzy, entuzjastów rewolucji, krytykuje ją pośrednio, w postaciach swoich bohaterów, w tym, co myślą i jak działają, a także gdy nie działają. Przykładem Rozmowy nad Nilem, gdzie formułą tytułowych rozmów jest „paplanina” czy „gadanina”, na co zresztą wskazuje użyte w tytule słowo arabskie sarsara, przybliżające nieskładny z założenia język narkomanów, protagonistów powieści. Zgodnie z techniką „strumienia świadomości” grupa intelektualistów toczy swoje rozmowy, popadając w rajski stan niebytu na barce kairskiej - palarni haszyszu. Ta grupa to reprezentacja elity intelektualnej, zamykającej się w swojej wieży z kości słoniowej, by odmówić udziału w budowaniu porewolucyjnej rzeczywistości. Nadżib Mahfuz jednak przy całym swoim krytycznym stosunku do rewolucji rozważa, na ile hartuje ona jednostkę i czy przypadkiem socjalizm, któremu przecież hołdował już w okresie młodzieńczym, nie jest słusznym wyborem politycznym. W As-Siman wa-al-charif Ali Isa Ataba, działacz słynnej partii liberalnej Al-Wafd, głównej siły przedrewolucyjnej będącej w opozycji do kolonializmu, po 1952 roku traci majątek, co jednak nie zdoła skłonić protagonisty do pracy, być może wyjściem jest udział w socjalistycznej przebudowie państwa ${ }^{10}$.

\footnotetext{
9 Por. R. Allen, An Introduction to Arabic literature, Cambridge 2003, s. 187.

10 Por. J. Bielawski, K. Skarzyńska-Bocheńka, J. Jasińska, op. cit., s. 482.
} 
Skoro nawet Nadżib Mahfuz zdobywa się na tak szczególny krok wobec rewolucji i jej następstw, cóż mogą powiedzieć inni? Numan Aszur, Sad an-Nin Wahba, Lutfi al-Chuli, nawet Taufik al-Hakim dowodzą w swoich utworach, że rewolucję warto wypróbować. Z Al-Ajdi an-na'ima (Delikatne ręce), sztuki Al-Hakima, pochodzi postać podobna do Alego Isy Ataby z powieści Mahfuza: gdy mija pierwszy, porewolucyjny wstrząs, arystokrata zubożały w wyniku nacjonalizacji i reformy rolnej zabiera się z dobrym skutkiem do pracy, aby osiągnąć stabilizację i zadowolenie ${ }^{11}$.

Z literatury egipskiej wyłania się też krytyka okresu przedrewolucyjnego, oznaczająca zapowiedź lepszej, porewolucyjnej przyszłości i wiarę w przewidywaną utopię; jej przykładem był już cytowany fragment ze sztuki Sad ad-Dina Wahby. Autorzy szermują pomysłami: marzenia chłopaka i dziewczyny o nowym Egipcie w In-nas illi taht (Ludzie na dole) Numana Aszura nie mogą się spełnić, chłopi nie są w stanie wygrać z ziemiaństwem w Al-Ard (Ziemia) Abd ar-Rahmana asz-Szarkawiego czy Il-Mahrusa (Chroniony Egipt) Wahby.

Rewolucje i wielkie wydarzenia polityczne wywołują w pisarzach z całego świata arabskiego zrozumiały niepokój, czemu dają wyraz w literaturze. Prozaik z Iraku, Abd ar-Rahman ar-Rubaji, późniejszy emigrant do Tunezji, podjął w swoich opowiadaniach i powieściach wątki wynikające z wydarzeń, które przetoczyły się w XX wieku przez jego kraj. Młodzież konspiruje przeciwko Anglikom, władzy królewskiej, a potem rodzinnym rządom w takich powieściach Ar-Rubajego, jak: Al-Wakr (Gniazdo), Al-Waszm (Tatuaż) i Al-Anhar (Dni).

W Al-Waszm, debiucie powieściowym pisarza, rysuje się zapowiedź decydującej przemiany w Iraku - w 1958 roku upada monarchia, powstaje republika, wydarzenie okrzyknięte rewolucją. Jeśli tak, porewolucyjny Irak jest rozchwiany, niestabilny, a w fabule Al-Anhar pojawia się kolejne powstanie, tym razem zmiany będą bardziej radykalne i potrwają dziesiątki lat. Rozpoczyna się przewrót, który Socjalistyczna Partia Odrodzenia Arabskiego Al-Bas, zorganizowała w 1968 roku, choć powieść nie wspomina tego wydarzenia z jego nazwy. W jakiś czas później, w początkach lat 70., w oczach protagonisty, irackiego malarza (może porte-parole Ar-Rubaj'iego, absolwenta bagdadzkiej Akademii Sztuk Pięknych), przywołującego wielkość Iraku w symbolu Gilgamesza, świat pozostaje mroczny i niepokojący. Przemiany nie idą w oczekiwanym kierunku.

Nową rzeczywistość w Syrii, po wyjściu Francuzów i w następnych dekadach, w jasnych barwach obrazuje jeden z najwybitniejszych pisarzy tego kraju i nestor jego literatury, Hanna Mina. W trylogii Hikajat al-bahhari (Historia marynarza), Syria jest już niepodległym, wolnym krajem i główny bohater w odróżnieniu od swojego ojca, dzielnego kapitana i bohatera ruchów narodowo-wyzwoleńczych przeciwko kolejnym hegemonom kraju, Turkom i Francuzom, nie może dowieść patriotyzmu w walce z zewnętrznym wrogiem. Wynika stąd laudacja dla przemian politycznych, a punkt ciężkości przesuwa się na przeobrażenia społeczne i obyczajowe. Występują tendencje do unowocześniania i westernizacji różnych sfer życia, społeczeństwo syryjskie ociera się o globalizację, choć nienazwaną po imieniu ${ }^{12}$.

Znawca powieści syryjskiej, Yousef Sh’hadeh klasyfikuje, m.in. ze względu na ten utwór, twórczość Miny jako realizm socjalistyczny ${ }^{13}$. Tu jednak warto rozważyć, czy nurt arabskiej literatury dokumentujący i opisujący nową rzeczywistość postkolonialną z jej podstawowymi uwarunkowaniami, nurt, do którego należą, przynajmniej częściowo, utwory syryj-

\footnotetext{
11 Por. ibidem, s. 203.

12 Y. Sh'hadeh, Syryjska powieść po roku 1961, Kraków 2007, s. 168.

13 Ibidem, s. 62.
} 
skiego autora, pozwala nazwać się socrealizmem? Termin europejski byłby zastosowany do twórczości innego kręgu kulturowego. Wydaje się to ryzykowne, zwłaszcza w tym wypadku, ponieważ termin ten jest kontrowersyjny. W Europie i w Polsce kojarzy się z twórczością pełną patosu, o dość jaskrawej, jednoznacznej ideologii, bez rozbudowanych warstw znaczeniowych. Tymczasem w prozie Hanny Miny wiele jest subiektywizmu, wyraża ona wewnętrzne przeżycia jednostek, starcza w niej miejsca, aby łączyć realizm obyczajowy, społeczny i polityczny z psychologicznym. W utworach pisarza syryjskiego jednostka odznacza się głęboką wrażliwością, a w planie pierwszym umiejscowione są jej przeżycia. Kluczowe zjawiska i wydarzenia wyłaniają się dopiero drogą uzewnętrzniania głębszych uczuć, skąd wynika atmosfera niepewności i niepokoju, w której przemiany rysują się jako żmudny i delikatny proces.

Niepokój odczuwają wszyscy twórcy arabscy poświęcający swoje fabuły przemianom, zawsze radykalnym - niezależnie od tego, czy koncentrują się na ich kontekstach politycznych, obyczajowych, społecznych. Jeden z najwybitniejszych marokańskich realistów Mubarak Rabi w Ar-Rih asz-szitawijja (Zimowy wiatr) opisuje Maroko kolonialne z jego buntami, rozruchami, protestami ludności i wielkim strajkiem robotniczym. W powstałym tumulcie zachodzą nie tylko zmiany polityczne, ale i przyspieszone przeobrażenia społeczno-obyczajowe. Młoda kobieta z konserwatywnej wsi marokańskiej, wierna tradycji miejscowej i arabskiej, teraz zostaje robotnicą, narażoną codziennie na męską brutalność zagrażającą jej zarówno pod względem ekonomicznym, jak i obyczajowym. W powieści At-Tajjibun (Dobrzy ludzie) tego samego pisarza młode pokolenie z trudem odnajduje się w postkolonialnym, rozchwianym Maroku, zbierając siły do przetrwania, a później - nieubłaganego rozwoju. Podobnym krajem jest Algieria po wojnie narodowo-wyzwoleńczej lat 50. i 60. w powieści Syryjczyka Hajdara Hajdara Walima li-aszab al-bahr (Uczta morskich traw), otrząsająca się z kataklizmów, ponawiając pytanie o swoją tożsamość. Powieść rozważa miejsce Algierii w trzech kręgach kulturowych: afrykańskim, francuskim i arabskim, z akcentem na ten ostatni. Kluczem do przemian jest język, źródło spójności kultury algierskiej i łącznik z całością świata arabskiego. Emigrant z Iraku, przecież średniowiecznej kolebki cywilizacji muzułmańskiej, uczy arabskiego jasnowłosą Algierkę, która choć urodę odziedziczyła po swoim francuskim dziadku, czuje się Arabką.

W arabskiej literaturze temat przeobrażeń to wielkie pole manewrów literackich, ich wątki rysują się od konkretnych po niedopowiedziane i słabiej uchwytne, towarzyszy im zarówno optymizm, jak i - zwłaszcza w miarę upływu czasu upływającego od decydujących wydarzeń - pesymizm, rozczarowanie i bunt. Arabski świat przedstawiony w trakcie przemian wyłaniający się z literatury, prozy i dramatów twórców z różnych krajów, tworzy jedną wielką całość, rodzaj fresku, a zarazem wyraża dynamiczny proces rozwojowy. Twórczość ta jest też rodzajem zbioru „pseudo-dokumentów”, czemu sprzyja linearny czas, urozmaicany przez retrospekcje oraz wierność kategorii przyczynowości.

\section{Świat na tle historii}

W miarę rozwoju literatury arabskiej, fabuły wymykają się uwarunkowaniom czasu linearnego i układów przyczynowo-skutkowych, wyrażają tendencję do swobodnego obrazowania idei, pomysłów i wątków w formie mozaiki, za pomocą techniki montażu filmowego. 
Treściom utworów zapewnia spójność czas synchroniczny. Jego linie w niewielkim stopniu warunkują się wzajemnie, raczej nakładają na siebie i przecinają, łącząc w sposób fantazyjny punkty przestrzeni ${ }^{14}$. W skrajnych wypadkach porządek temporalny jest abstrakcją, świat przedstawiony rysuje się w ponadczasowej przestrzeni albo też płaszczyzny czasowe zlewają się i łączą w umowną całość.

Ta konwencja literatury arabskiej wydaje się możliwa dzięki temu, że świat po decydujących przemianach został już - czy też jest nadal - obrazowany przez zwolenników pisarstwa, które nie ujmując mu walorów literackich, można nazwać „pseudo-dokumentalnym”.

W nowym ujęciu pisarze zyskują swobodę twórczą i wykorzystują ją do kreowania wieloznacznych obrazów i fabul, do których klucza trzeba szukać w głębszych pokładach semantycznych. Literatura ta jest przesiąknięta symboliką, pozwalającą jednak wydobywać z niej czytelne przesłania. Pozwala też przypuścić, że współczesność ukrywa się w szatach historycznych, w których jej wymowa wzmaga się na tle znaczeń uniwersalnych. Konwencja ta wynika przede wszystkim z dramaturgii arabskiej od lat 60 . w Egipcie i z różnymi przesunięciami w czasie - rozwijającej się w innych krajach regionu. Mam tu na myśli zwłaszcza twórczość tak wybitnych dramatopisarzy, jak Mahmud Dijab, Jusuf Idris (19271991; Egipt), Mu'ina Basisu (Palestyna), Sad Allah Wannus (Syria) Izz ad-Din al-Madani (Tunezja). Na kanwie historii, legend i tradycji rozwija się arabski teatr XX wieku oparty na tekście literackim, który odwołuje się zwłaszcza do tradycji widowisk epickich kwitnących na ziemiach muzułmańskich w okresie klasycyzmu. I we współczesnych dramatach narrator stanowi spiritus movens fabul, skomponowanych jako opowiadane przez niego historie. Podobną konwencję widać w prozie, np. w utworach Egipcjan, Dżamala al-Ghitaniego (ur. 1945) i Jahji Tahira Abd Allaha, które choć brak w nich tej postaci ludowego artysty jako ucieleśnionej, są tak skomponowane, jakby ich treść on właśnie opowiadał.

Przede wszystkim z tak pojętej dramaturgii wyłania się człowiek o podwójnym obliczu, z jednej strony jest uniwersalny i niedopowiedziany, z drugiej zaś ściśle określony: dynamiczny i wyrażający protest przeciwko systemom władzy. Teatr ten można pojmować jako upolityczniony i walczący, zwłaszcza gdy w swoich historycznych szatach, nie unika skojarzeń ze współczesnością.

Utopię niszczycielskiej dla obywateli władzy jako jeden z pierwszych rozwija Jusuf Idris w swoich szukach Il-Farafir (Błazny) i Il-Muchattatin (Pasiaści ludzie), w których odwołuje się do ludowości i siega po abstrakcję. W pierwszej Pan i Błazen, którzy z woli zbyt zajętego autora mają sobie stworzyć świat przedstawiony w ramach granej sztuki, nie zdołają znaleźć odpowiedniego ustroju - jedna z dobrych przyczyn dla ich błazeńskiego samobójstwa. Druga sztuka dowodzi niezniszczalności raz uznanej władzy, sięga po stereotyp rozfanatyzowanego tłumu, pełnego dla niej uwielbienia, postawy wpojonej odgórnie poddanym czy obywatelom. W Il-Muchattatin przywódca rewolucji, której symbolem są czarno-białe pasy, wobec entuzjazmu mas nie jest w stanie podjąć próby zniszczenia stworzonego przez siebie monstrum, jakim jest porewolucyjne państwo. Niezmienność i trwałość powstałego status quo staje się przeciwieństwem ideologii przemian jako układu odniesienia, analizowanej z troską w nurcie literatury, opisanym wcześniej. W Syrii, jeden z najwybitniejszych drama-

${ }_{14}$ Ujęcie czasu na podstawie koncepcji E. T. Halla w: Ukryty wymiar, Warszawa 1976, s. 243; por. I. Sławińska, Współczesna refleksja o teatrze. Ku antropologii, Kraków 1979, s. 357 
turgów arabskich, którego twórczość jest uznana za polityczną ${ }^{15}$ podkreśla beznadziejność wynikającą z braku perspektyw zmian w strukturach rzeczywistości, co wyraża m.in.w sztuce Fasd ad-dam (Upust krwi). Tu mężczyzna, kobieta i dziecko nie próbują zaznaczyć swojego istnienia inaczej niż potakującym, automatycznym ruchem głowy. Wannus jest jednak jednym z pisarzy, kreślących kontury historyczne dla trudnego do opisania państwa-monstrum, którego wszechobecność w formie abstrakcyjnej zarysował Jusuf Idris (pisał o tym wcześniej niż Wannus). Pisarz syryjski nazywa ten twór po imieniu: to kalifat z okresu swojego rozpadu, bo przecież w czasach tego właśnie państwa przydarza się dziwna historia jako temat jego dramatu Mughamarat ras al-mamluk Dżabir (Przygody głowy niewolnika Dżabira), w którym tytułowy bohater ma przenieść na swojej ogolonej głowie list z prośbą o pomoc dla oblężonego miasta, po czym - po wykonaniu zadania - nie otrzymuje nagrody, lecz zostaje ścięty. Motyw złowrogiego państwa wyłaniającego się z twórczości tego pisarza łączy historię ze współczesnością, kojarzy się też z treścią sztuki Wannusa Masat ba'i ad-dibs al-fakir (Męka biednego sprzedawcy melasy) jako brutalnej analizy stopniowego wyniszczenia protagonisty w toku ponawianej inwigilacji policyjnej.

Wydarzenia składane są przez autorów w wybranym przez nich porządku, ilustrującym fatalną tezę o trudnym przeznaczeniu ludzkim i obywatelskim. Dlatego zlewają się płaszczyzny czasowe w utworach łącząc wieki. W Bab al-futuh (Rozdział o podbojach) Mahmuda Dijaba (1932-1983) hiszpański muzułmanin udaje się na wschód do Saladyna, aby prosić o pomoc dla zagrożonej upadkiem Andaluzji, ale nie jest w stanie pokonać machiny biurokratycznej i dotrzeć przed oblicze władcy, co milcząco obserwuje chór postaci z XX wieku. Wydaje się, że dramatopisarze nie mniej martwią się o przemiany w swoich krajach i na świecie, co twórcy uprzednio opisanego nurtu, nazywający rzeczy po imieniu. Są jednak bardziej krytyczni, dowodzą trwałości złowrogiego status quo jako stanu zachęcającego, czy się tego chce, czy nie chce, do walki.

Zachęta do buntu i walki płynie m.in. z dramatu Raszszada Ruszdiego (1912-1983) Baladi ja baladi (Kraju, mój kraju) reprezentatywnego dla dramaturgii pseudo-historycznej, utrzymanego w konwencji teatru w teatrze. Egipski zespół uliczny gra sztukę o ludowym świętym z Tanty, Ahmadzie al-Badawim, który żył siedemset lat wcześniej i którego kult trwa po dzień dzisiejszy. Obie płaszczyzny czasowe zlewają się i przenikają. Święty odrzuca postawę cudotwórcy, służy radą, swoją charyzmą pociąga tłumy do wiary, ale zachęca do samodzielności i aktywnego działania, bez odwoływania się do sił nadprzyrodzonych, których łaskawość skłaniać będzie do bezradności i bierności, i pod wpływem tej postawy ruch ludowy zaczyna zagrażać brutalnej władzy. Szczególnie dzięki synchronii czasu, od lat 60. kontekst historyczny jest dla dramaturgów swojego rodzaju pretekstem dla krytyki zjawiska przemocy od czasów najdawniejszych po dzień dzisiejszy. Niechętnie użyłabym tu słowa kamuflaż, ponieważ kojarzy się ono z pewnym udawaniem, a nawet oszustwem, choćby w najlepszej wierze. Dramatopisarze arabscy są dalecy od takiej postawy, temat kondycji ludzkiej, który ich pociąga, wielu prowadzi prosto w meandry współczesnej myśli i krytyki politycznej, autorzy piszą spontanicznie i szczerze, czego dowodzi ekspresywność utworów.

Izz ad-Din al-Madani (ur. 1939), znany dramaturg tunezyjski, i Mu'in Basisu (1926-1984), poeta palestyński, sięgający po dramat, podejmują w swoich utworach ten sam te-

${ }^{15}$ M. Dakrub, Kalima..., kitaba tantalik min al-mumarasa wa al-hiwar wa-al-ufk al-maftuh, [w:] Al-Amal al-kamila, S. Wannus, Dimaszk 1996, t. III, s. 10. 
mat - powstania Zandżów, czarnoskórych niewolników w irackich kopalniach soli, którzy w IX wieku uciekli się do zbrojnego działania przeciwko opresorom.

U Basisu przenikają się płaszczyzny czasowe, z okruchów wydarzeń historycznych i współczesnych powstaje świat ponadczasowy, alegoryczny i aluzyjny. W jego Saurat Az-Zandż (Rewolucja Zandżów) obok bohaterów obdarzonych imionami i nazwiskami, wśród których poczesne miejsce zajmuje przywódca ruchu Abd Allah Ibn Muhammad, przewijają się groteskowe postacie, jak Człowiek-Pralka, Człowiek-Trykot i Człowiek-Kalejdoskop, łącznicy płaszczyzn czasowych:

Obraz drugi.

Światła tworzą kwadrat dwa metry nad sceną. Ze wszystkich stron widać pomalowane na biało kopie, na niektórych zatknięto czerwone turbany, na innych czarne chustki. Światła oświetlają wyraźnie tę przestrzeń. Po prawej stronie znajduje się klasa szkolna z czarną tablicą na ścianie, podzieloną wzdłuż na dwie części. W pierwszej znajduje się napis Obalić Abd Allaha Ibn Muhammada, a w drugiej Pijcie, pijcie coca-colę.

Na stole pod tablicą umieszczono armatę z lufą skierowaną w środek oświetlonego kwadratu. W dwóch rzędach ustawiono po pięć krzeseł. Na każdym z nich przycupnęli dwaj chłopcy, pochłonięci pisaniem co jakiś czas spoglądają na tablicę. Człowiek-Pralka jako nauczyciel krąży między uczniami z długą linijką w ręce. Na scenę tę pada delikatne światło, podczas gdy cały czas mocno oświetlony jest obraz mieszczący się w opisanym kwadracie. Ktoś wyłania się z innego kąta, niosąc kalejdoskop na plecach. Idzie ciężkim krokiem przyglądając się wszystkiemu uważnie i dmie w trabkę:

Człowiek-Kalejdoskop: Kto ma czym zapłacić, niech patrzy,

kto nic nie ma, też zobaczy,

kalejdoskop darmo, kalejdoskop

(krąży po scenie).

Kalejdoskop dla tego, kto patrzy,

świat to jeden mlyn,

rankiem miele cukier, po południu sól,

o zachodzie słońca miele rękę młynarza,

kalejdoskop darmo... ${ }^{16}$.

W obu utworach tytułowa rewolucja ma wymiar symboliczny, postacie poruszają się w konwencji umowności, niczego nie kamuflując, lecz tocząc bolesną walkę o przetrwanie, każda grupa na własnych warunkach i na różnych płaszczyznach: historycznej, abstrakcyjnej i współczesnej. Pisarze różnie operują realiami historycznymi, każdy ma własny pomysł, jak je wykorzystać dla poprawy postkolonialnej rzeczywistości. Izz ad-Din al-Madani w swojej sztuce Diwan Az-Zandż (Dywan - antologia Zandżów) rozwija nie tylko myśl społeczno-polityczną, ale również ujawnia się jako teoretyk literatury i teatru. Podchodzi do powstania czarnoskórych niewolników Iraku inaczej niż Basisu, choć łączy ich ta sama postawa sprzeciwu i protestu wobec przemocy.

Dramaturg tunezyjski dzieli sztukę na dwie płaszczyzny, z których na pierwszej toczy się powstanie, mniej więcej zgodnie z prawdą historyczną, choć autor uwydatnia bohaterstwo, poświęcenie i biedę Zandżów. Na płaszczyźnie drugiej Al-Madani podkreśla znaczenie tytułowego tematu nie tylko dla historii, ale i współczesności, a także przykład ich powiązania na użytek literatury i sztuki teatru.

${ }^{16}$ Mu'in Basisu, Saurat Az-Zandż, [w:] Mu'in Basisu, Al-Amal al-kamila, Bajrut 1979, s. 163-164. 
Druga faza.

Jestem autorem Dywanu rewolucji Zandżów. Stworzyłem ten dywan teatralny na tle rewolucji, powstań i przewrotów, które wydarzyły się w połowie XX w. w wielu krajach trzeciego świata:

- Jak mamy zbudować nasz oryginalny arabski teatr maghrebiński?

- Na jakich zasadach go zbudujemy?

- Czy przez powrót do religii i jej obrzędów?

- Pogrążając się w dawnej historii?

- Mając na myśli aktualną teraźniejszość?

Odpowiem:

- Kto nie sięga po obrzędy religijne, nie pozna tajemnic ukrytych w spektaklu teatralnym.

- Kto nie zajmuje się dawną historią, nie zrozumie podstawowych zasad funkcjonowania społeczeństwa.

- Kto nie drąży rzeczywistości, ten traci ją z pola widzenia ${ }^{17}$.

Do historii i legend, jako kontekstu współczesnych wydarzeń, sięgają dramatopisarze iraccy, zwłaszcza Jusuf al-Ani, Adil Kazim, Kasim Muhammad, ponieważ w ich utworach tradycja przytłacza ze swoją siłą uniwersalizm, inaczej niż we wspomnianych dramatach Jusufa Indrisa, o przesłaniach odnoszących się zarówno do rodzimego, jak i obcego gruntu.

Al-Ani jako dramaturg przeszedł do historii zwłaszcza dzięki dramatowi A-Miftah (Klucz), w którym para małżeńska, wędruje w myśl słów ludowej kołysanki, dzięki czemu ma sobie zasłużyć na posiadanie upragnionego dziecka i zdolna będzie zapewnić mu godziwe życie. Choć przemierza swoją abstrakcyjną przestrzeń etapami, co kojarzy się z czasem linearnym, etapy te tworzą barwną mozaikę zwyczajów irackich i odniesień do Iraku. Czas synchroniczny lączy historię, legendy i tradycję w dramacie Adila Kazima Al-Maut wa-alkadijja (Śmierć i sprawa), w której Rewolucjonista, abstrakcyjny, pełen zapału - pozwalając się odbiorcom dowolnie skonkretyzować - schodzi w czasy Szeherezady, a rozmowa narratorki Księgi tysiąca $i$ jednej nocy z rewolucyjnym bohaterem, brzmi jak manifest całej dramaturgii pseudohistorycznej:

Szeherezada: Skąd jesteś ?

Rewolucjonista patrzy na nią, po czym siada.

Szeherezada: Ubierasz się tak dziwnie...

Rewolucjonista: Moje ubranie oddaje ducha epoki.

Szeherezada: Co masz na myśli?

Rewolucjonista: Chcę powiedzieć, że znajduję się w odpowiednim miejscu i czasie.

Szeherezada: Nie rozumiem.

Rewolucjonista: Mam przez to na myśli, że trzymam w ręku historię.

Szeherezada: Nic nie rozumiem.

Rewolucjonista: Ponieważ jesteś pogrążona w marzeniach.

Szeherezada: Skąd wiesz?

Rewolucjonista: Ponieważ trzymasz w ręku zabawkę.

Szeherezada (wskazuje na jego pistolet): Co z tym robisz?

Rewolucjonista: Poluję na trochę wilków. Ich głos męczy mój naród.

Szeherezada: Masz naród?

${ }_{17}$ Izz ad-Din al-Madani, Diwan Az-Zandż, Tunus 1973, s. 99-50. 
Rewolucjonista: Na całym świecie.

Szeherezada: Jak się nazywasz?

Rewolucjonista: Jestem Rewolucjonista ${ }^{18}$.

Szeherezada, coraz bardziej świadoma swojego skostnienia w efemerycznym świecie marzeń, stopniowo zaczyna patronować walce Rewolucjonisty, rozpaczając i obiecując zemstę, gdy zraniony umiera na jej piersi.

Świat arabski, bogaty w dobra kulturalne, monumentalną historię i niepowtarzalne legendy, jest wdzięcznym terenem dla wędrówek po czasie i przestrzeni, jakie obok dramatopisarzy odbywają w utworach poeci, prowadząc tym szlakiem swoich epickich bohaterów, z którymi utożsamiają poetyckie ja. Historia jest pasją Arabów, tematem nieustannych dyskusji w gronach intelektualistów, a także pryzmatem, przez który pojmowany jest świat współczesny i, oczywiście, jak wynika choćby z powyższego, niebagatelnym motywem literackim. Bujna historia, tak jak klasycyzm i język pozostaje skarbem dla współczesnych, który jednak nie ma spoczywać bezpiecznie w skarbcu, lecz służyć pomnażaniu wspólnego dorobku.

Historia jest częścią turasu - spuścizny historyczno-kulturowej, do której, jak zachęca Izz ad-Din al-Madani, warto powracać w kategoriach asali (autentyzm, całkowite uczestnictwo w kulturze) oznaczającej wierność pochodzeniu i zdobyczom przeszłości ${ }^{19}$.

Nowatorski teatr po okresie, w którym literatura rozwija świadomość nowoczesnego państwa w mentalności arabskiej, przypomina o bogatej przeszłości swojego obszaru i nawołuje do poczucia dumy narodowej. Głosi, że rewolucje rozpoczynające się przed wiekami wciąż trwają i przybierają formę rozruchów i powstań przeciwko współczesnej władzy. Być może dramatopisarze od lat 60., a zwłaszcza - po klęsce czerwcowej 1968 roku po lata 70., byli swojego rodzaju wizjonerami, skoro ich koncepcje, w kilka dekad później, znalazły swój wyraz w masowych ruchach rewolucyjnych arabskiej wiosny 2011 roku.

Dramaturgię arabską znamionuje ton pesymistyczny po latach, jakie minęly od decydujących przemian, które nastąpiły w XX wieku w poszczególnych krajach. W smutku i żalu twórczości tej sekunduje współczesna poezja, obrazując bolesną rzeczywistość jako kalkę przeszłości.

Głęboki, tragiczny wydźwięk ma proza, choćby na kilkunastu tysiącach stron powieści i opowiadań Abd ar-Rahmana Munifa. Jego pięcioksiąg Mudun al-milh (Miasta soli) opowiada o upadku świata Beduinów po odkryciu ropy naftowej oraz gwałtownej komercjalizacji i globalizacji ich obszarów ${ }^{20}$. Znamienne, że Munif jest jednym z twórców nurtu „literatury więziennej” (obok Zakarijji Tamira czy Nun Allaha Ibrahima; należy tu też Karnak Nadziba Mahfuza), do której wypada zaliczyć jego Szark al-Mutawassit (Na wschód od Morza Śródziemnego), o więźniu politycznym zamęczonym na śmierć przez funkcjonariuszy aparatu bezpieczeństwa w nienazwanym państwie arabskim.

Nie tylko w kontekście historycznym, lecz także współczesnych jej nurtów literackich, dramaturgia wyraża protest przeciwko regresywnym tendencjom politycznym, zwłaszcza tym, które doprowadziły do klęski 1967 - przegranej wojny arabsko-izraelskiej.

${ }^{18}$ Adil Kazim Dżawad, Al-Maut wa-al-kadijja, Bagdad b.d., s. 62.

19 Izz ad-Din al-Madani, Bajan haul istimal al-fada al-masrahi fi haza ad-diwan, [w:] Izz ad-Din al-Madani, Diwan Az-Zandż, s. 12.

20 Por. Allen, op. cit., s. 188. 


\section{Świat poznawany}

Literaturę, którą mam tu na myśli, można by nazwać egzystencjalną, gdyby nie to, że termin ten w literaturoznawstwie ma swoje przyjęte konotacje, gdzie oznacza twórczość wyrażającą pustkę i beznadziejność egzystencji. Ta zaś literatura arabska stanowi przeciwieństwo takiego rozumienia, jest pogodna, czasem refleksyjna, kiedy indziej żarliwa. Nie wystarczy powiedzieć, że to pisarstwo poszukujące prawdy, gdyż takie jest zadanie zapewne wszelkiej literatury. Poszukiwania dotyczą mądrości i przykładów wynikających z kondycji ludzkiej i świata. Ta mądrość odpowiada pojęciu starej arabskiej hikmy, pozwalającej docierać do sedna rzeczy przy pomocy paraboli albo też jednoznacznej, celnej wypowiedzi. Literatura ta nie ma tak szczególnego i z uporem osiąganego celu, jakim jest w twórczości pseudo-historycznej obnażanie mechanizmów despotycznej czy totalitarnej władzy i biedy uwikłanego w nie człowieka. Celem jest poznanie i mądrość sama wynikająca z celnej anegdoty czy opowieści, formy, w których pobrzmiewa tradycja adabu - klasycznej prozy rozrywkowo-pouczającej. Mądrość ta daje do myślenia, zadziwia, upraszcza złożoność. Jeśli realiści wychwytują szczególnie zjawiska typowe, pisarstwo to sięga po sytuacje tak bardzo nietypowe, że godne uwagi. Jako przypowieści można odczytać opowiadania Izz ad-Dina al-Madaniego Hikajat al-bab (Historia drzwi) i Hikajat al-dżamal (Historia wielbłąda). W pierwszym więzień ma obiecaną natychmiastową wolność, jeśli znajdzie wyjście z celi. Wszelkie próby się nie udają, a po latach dowiaduje się, że gdyby pociągnął drzwi do siebie, czego nie zrobił, byłby wolny. W drugim, ponieważ mędrzec nie wie, jakie imię nadać cudownej urody wielbłądkowi, a jego konsternacja już za długo trwa, nakazuje wyłupić zwierzęciu oko i nazwać je jednookim.

Ponieważ w podróżach spotyka się rzeczy dziwne i niezwykłe, które opisywał już narrator Isa w Makamach Badi az-Zaman al-Hamadaniego, przykładem opisywanej „twórczości poznawczej” jest arabska literatura drogi. W niektórych utworach egipskich autorów, Dżamala al-Ghitaniego i Salwy Bakr, droga prowadzi po krajach arabskiego średniowiecza.

W powieści Al-Ghitaniego Hatif al-maghib (Zew nieznanego) średniowieczny mędrzec wędruje z Egiptu do Maroka; kierując się wewnętrznym głosem pokonuje bezdroża pustyni. Sam nie wie dokąd zmierza, ale jako cel wędrówki intuicja podsuwa mu poznanie, a na swojej drodze spotyka zadziwiające królestwa. Podróż kończy się u wód Oceanu Atlantyckiego - miejsca pojmowanego w średniowieczu jako kres ziemi, które jest też kresem podróżnika.

Poznanie jest też najwyższym celem wędrowców w zbiorze opowiadań Al-Ghitaniego Mutun al-Ahram (Grzbiety Piramid).

Od dziecka odwiedzał szajcha, aby zdobywać wiedzę i mądrość. Był jeszcze młody, kiedy przejechał Bliski Wschód i zwiedził krainę Zandżów. Gdy usłyszał o karawanie wiozącej pielgrzymów do Mekki, poczuł tęsknotę do świętych miejsc. Poradził się szajcha, który gorąco przyklasnął jego podróży. Był więc już pewny, że może wyruszyć. Jechał pokonując gładko kolejne etapy, a w głowie miał tylko pielgrzymkę i obrzędy. Oczyścił się, zanim stanął na ziemi Al-Hidżazu i w modlitwie wyznawał posłuszeństwo Bogu. Okrążał świątynię, biegł między świętymi wzgórzami i pił wodę z Zamzamu. Stanął na Arafacie, gdzie wzywał Boga. Szedł razem z tłumem i wraz ze wszystkimi tymi ludźmi spojrzał po raz pierwszy na Kabę otuloną jej czarną zasłoną. 
Widział pielgrzymów cisnących się w kierunku Muzdalify w ich białych strojach w mroku nocy, w świetle pochodni migoczących na tle otaczających, masywnych gór. Odwiedził też grób Proroka Muhammada - Al-Mustafy. Wrócił ze swoją grupą i zanim zdążył odpocząć, pobiegł do mądrego szajcha, aby mu wszystko opowiedzieć. Szajch wysłuchał z uwagą całej opowieści, po czym zapytat:

- Opowiedz mi o Piramidach i jak je znalazłeś:

Młodzieniec zlodowaciał:

- Nie widziałem niczego, o czym mógłbym opowiedzieć - rzekł.

Szajch odwrócil twarz.

- Cóż to za student, który pragnie wiedzy i mądrości, a nie spieszy zobaczyć czegoś godnego podziwu i nie interesuje się niezwykłym widokiem. Czy dwukrotnie nie przejeżdżałeś przez Kair? Młodzieniec potakująco skinął głową.

- Czy nie dzielił cię od Piramid jeden koński skok albo krótki rejs łodzią? Czy nie brak ci więc zapału? Inaczej, jak to nazwać?

Po czym szajch odwrócił się od niego i zamilkł. Młodzieńcowi nie pozostawało nic innego, jak tylko wycofać się i odejść. Od tego czasu szajch nie interesował się nim ani nie pytał o niego. Młodzieniec zrozumial, że już nic nie znaczy dla mędrca. Skończyły się lata jego stabilizacji, powinien więc wyjechać ${ }^{21}$.

W powieści Salwy Bakr Al-Baszmuri (Baszmuryjczyk) średniowieczny Kopt z koptyjskiego odłamu Baszmurów, najpierw przemierza Egipt w tajnej misji, a potem gdy dostanie się do niewoli, również Bliski Wschód, aby w końcu wrócić do klasztoru pod Kairem.

Proces poznawczy i wiedza wynikająca z doświadczenia rysują się jako cel i tworzywo literackie w pisarstwie Jahji Tahira Abd Allaha ${ }^{22}$ z Egiptu i At-Tajjiba Saliha ${ }^{23}$ z Sudanu, którzy dostrzegają mądrość wynikającą z tradycji i przesiąkniętą ludowością. Wówczas turas nie jest źródłem niepokoju, jak w twórczości pseudohistorycznej, ale zbiorem pomysłów i form, z których można czerpać pociechę, dystans do świata i wreszcie środki na przetrwanie.

Literatura współczesna po epoce klasycyzmu i kolonializmu w świecie arabskim nacechowana jest entuzjazmem twórców, wchodzących w coraz bliższe kontakty z Europą, których ślady spotyka się w utworach. Czasem może się wydawać uprawnione przenoszenie nazw całych europejskich kierunków literackich na twórczość arabską. Niemniej w trakcie rozwoju charakteryzuje ją w coraz większym stopniu tendencja narodowa i nierozerwalne związki z otaczającą rzeczywistością. Niezależnie od tego, czy o konstrukcji fabuły decyduje diachronia czy synchronia, wyłania się też z niej niezmiennie motyw walki.

21 Dżamal al-Ghitani, Matn awwal (493-509), [w:] Al-Amal al-kamila, Dżamal al-Ghitani, Al-Kahira 1996, t. VI, s. 500-501.

${ }_{22}$ Zwłaszcza: Jahja Tahir Abd Allah, Hikajat li-al-amir hatta janam, [w:] Al-Kitabat a.-kamila, Jahja Tahir Abd Allah, 1994, s. 257-410.

${ }^{23}$ At-Tajjib Salih, Bandarszah, Bajrut 1978, Wesele Zajna, tłum. J.Kozłowska, Sopot 2010. 


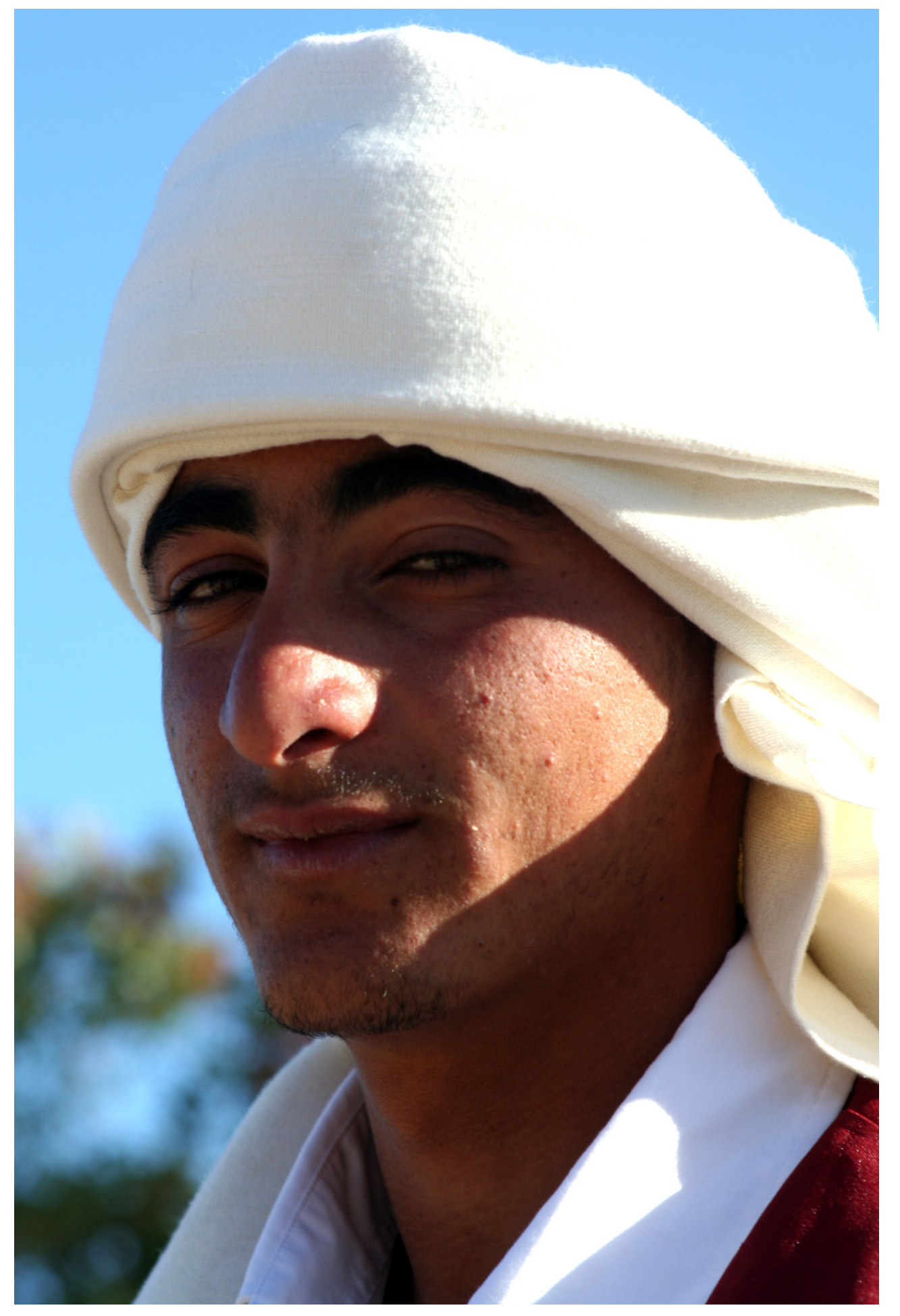

Mieszkaniec wyspy Dżarba, Tunezja

(fot. Z. Preisner) 